\title{
Clinical Complications of Iron Overload in Patients with Myelodysplastic Syndromes: a literature review
}

\author{
Luiz Gustavo Almeida de Carvalho 1,2*, Andressa Hellen de Morais Batista 1, Isabelle Cerqueira Sousa 1 \\ ${ }^{1}$ Centro Universitário Christus - Unichristus, Fortaleza, CE, Brasil. \\ ${ }^{2}$ Post-Graduation Program in Translational Medicine, Federal University of Ceará, Ceará, CE, Brazil. \\ *Corresponding author: Luiz Gustavo Almeida de Carvalho. Rua Fiscal Vieira, $n^{\circ}$ 3330, Apto 18 - Joaquim Távora. \\ Zip Code: 60120-170 - Ceará, CE, Brazil. Phone: +55 (85) 9 8125-4992. E-mail: lgcarvalho.biomed@hotmail.com
}

Received on: May 31, 2021. Accepted on: Jun 10, 2021. Available online: Jun 18, 2021.

\section{Resumo}

Myelodysplastic Syndromes (MDS) are a group of heterogeneous hematologic disorders characterized by bone marrow involvement. Iron overload is the result of multiple transfusions and high levels of apoptosis. Based on a literature review, ferritin was identified as an important marker of iron accumulation in organs such as liver, heart and pancreas in patients with MDS. Some studies also demonstrated that iron overload caused cell cycle arrest causing apoptosis and progression to leukemia, high levels of reactive oxygen species and low levels of HIF-1a, causing apoptosis, being related to the presence of cytopenia in MDS.

Keywords: Myelodysplastic syndrome; Iron overload; Clinical complications.

\section{Introduction}

Myelodysplastic Syndromes (MDS) are a group of heterogeneous hematologic disorders characterized by compromised bone marrow function, ineffective hematopoiesis, cytopenias and increased risk of progression to Acute Myeloid Leukemia (AML). It is a disease that predominantly affects the elderly, although it can occur at any age $[1,2]$.

MDS can be primary, that is, when it appears without a defined etiology, affecting mainly individuals over 60 years of age, or secondary with the appearance after exposure to chemotherapy agents, radiotherapy agents or autologous transplants [3]. According to the 2016 World Health Organization (WHO) Classification for hematopoietic and lymphoid tissue tumors, the categorization of MDS is based on the assessment of peripheral blood and bone marrow morphology, in addition to cytogenetic and molecular analysis. Its categories include MDS with single-lineage dysplasia, MDS with ringed sideroblasts, MDS with multilineage dysplasia, SMD with excess blasts, MDS with isolated del (5q), and unclassifiable SMD [4].

The International Prognostic Scoring System (IPSS), its revision (IPSS- 
R) and the WHO Prognostic Scoring System (WPSS) are important standards for assessing the prognosis of adult patients with primary MDS not treated. Cytogenetic clusters are also valuable for prognosis and for refining features used in IPSS [5]. As a consequence of ineffective hematopoiesis, most patients with MDS (approximately $60 \%$ to $80 \%$ ) have anemia, the main one being cytopenia and about $40 \%$ of these need transfusional support during the course of the disease [6].

Each unit of red blood cells for transfusion contains 200 to $250 \mathrm{mg}$ of iron, which is released as red blood cells are cleared from the circulation. Prolonged exposure to transfusions makes MDS patients more susceptible to iron overload, evidenced by high levels of serum ferritin, and its clinical consequences, being strongly linked to decreased overall survival [7].

Excess iron increases the production of reactive oxygen species (ROS), increasing oxidative stress and causing disturbances in the hematological niche, compromising hematopoiesis, in addition to oxidizing lipids, proteins and nucleic acids, resulting in apoptosis, cell death, tissue and organ damage, which if left untreated can lead to death $[4,6]$.

Iron chelation therapy is a therapeutic option to prevent the possible complications associated with regularly transfused MDS patients, improving hemoglobin and reducing the need for transfusions, indicating that iron overload prevents erythropoiesis. However, the mechanisms by which this occurs are not fully understood [6,7]. Given this problem, the objective of this study is to evaluate, through a systematic review of the literature, the consequences of iron overload in patients with Myelodysplastic Syndromes, the main mechanisms and organs affected by it.

\section{Methodology}

A literature search was performed by consulting the following databases: Pubmed, Lilacs and Scielo. The keywords used were selected by listing the following combinations: "Myelodysplastic syndrome", "Iron Overload", and "Complications".

The inclusion criteria used in this bibliographic search were: full text, written in Portuguese and English. The articles used were case-control studies, retrospective studies, bibliographic reviews and systematic reviews published between the years 2015 to 2018. From the totality of articles found, all those whose theme and objectives were not related were excluded.

\section{Results (Review)}

For systematic review, a search for descriptors in the databases was carried out, identifying 259 studies. Studies published in the last five years and studies only in humans were included, leaving 58 works. After reviewing the articles, 43 articles were excluded, two because they were 
written in Chinese and French, 26 because they were a literature review, 15 did not meet the objective of the study or fit some other exclusion criterion.

Of the 15 works that were read in full, 8 articles did not address the topic addressed and were excluded. After selecting the 7 articles, tables were formatted to present the results.

The selected studies reflect the relationship between iron overload in patients with MDS and its secondary complications. The distribution of studies included in the systematic review is shown in Table 1.

Table 1. Distribution of studies included in the systematic review, published between 2015 and 2018.

\begin{tabular}{|c|c|c|c|c|}
\hline $\begin{array}{l}\text { AUTHOR/ } \\
\text { YEAR }\end{array}$ & TITLE & COMPLICATIONS & $\begin{array}{c}\text { IPSS } \\
\text { SCORE }\end{array}$ & $\begin{array}{c}\text { IRON } \\
\text { CHELATING }\end{array}$ \\
\hline $\begin{array}{l}\text { Du Y, et } \\
\text { al. }(2017)\end{array}$ & $\begin{array}{l}\text { Observational Monitoring of } \\
\text { Patients with Aplastic } \\
\text { Anemia and } \\
\text { Low/Intermediate-1 Risk of } \\
\text { Myelodysplastic Syndromes } \\
\text { Complicated with Iron } \\
\text { Overload }\end{array}$ & $\begin{array}{l}\text { Iron deposits only in the } \\
\text { liver }(53.2 \%) \text {, in the heart } \\
(1.4 \%), \text { in the liver and } \\
\text { pancreas }(21.7 \%), \text { in the } \\
\text { liver and heart }(8.7 \%) \text { and } \\
\text { in the liver, heart and } \\
\text { pancreas }(10.1 \%)\end{array}$ & $\begin{array}{c}\text { Low } \\
\text { risk/Intermediate-1 }\end{array}$ & $\begin{array}{l}\text { There was a } \\
\text { significant } \\
\text { decrease in serum } \\
\text { ferritin when } \\
\text { using deferasirox } \\
\text { or deferoxamine }\end{array}$ \\
\hline $\begin{array}{l}\text { Zheng } \\
\text { QQ, et al. } \\
(2017)\end{array}$ & $\begin{array}{l}\text { Iron overload promotes } \\
\text { erythroid apoptosis through } \\
\text { regulating HIF-1a/ROS } \\
\text { signaling pathway in } \\
\text { patients with } \\
\text { myelodysplastic syndrome }\end{array}$ & $\begin{array}{l}\text { Inhibition of cell viability, } \\
\text { increased erythroid } \\
\text { apoptosis by increasing } \\
\text { levels of reactive oxygen } \\
\text { species and decreasing } \\
\text { HIF-1a, blocking the cell } \\
\text { cycle and increasing levels } \\
\text { of reactive oxygen species }\end{array}$ & $\begin{array}{l}\text { Low } \\
\text { risk/Intermediate-1; } \\
\text { High } \\
\text { risk/intermediate-2 }\end{array}$ & $\begin{array}{l}\text { Reversed the } \\
\text { effects caused by } \\
\text { iron overload with } \\
\text { the use of } \\
\text { deferiprone. }\end{array}$ \\
\hline $\begin{array}{l}\text { Hua } Y \text {, et } \\
\text { al. (2017) }\end{array}$ & $\begin{array}{l}\text { Iron overload may promote } \\
\text { alteration of NK cells and } \\
\text { hematopoietic } \\
\text { stem/progenitor cells by JNK } \\
\text { and P38 pathway in } \\
\text { myelodysplastic syndromes }\end{array}$ & $\begin{array}{l}\text { Decreased P38 expression } \\
\text { in NK cells, cell cycle } \\
\text { arrest, increased } \\
\text { apoptosis; increased p38 } \\
\text { expression in CD34 + cells; } \\
\text { transformation into LMA }\end{array}$ & $\begin{array}{l}\text { Very low risk; low; } \\
\text { intermediary; high; } \\
\text { very high }\end{array}$ & $\begin{array}{l}\text { It reversed the } \\
\text { effects of iron } \\
\text { overload and } \\
\text { extended life. It } \\
\text { did not detail } \\
\text { which chelator } \\
\text { was used }\end{array}$ \\
\hline $\begin{array}{l}\text { Waszczuk- } \\
\text { Gajda, et } \\
\text { al. (2016) }\end{array}$ & $\begin{array}{l}\text { Red Blood Cell Transfusion } \\
\text { Dependency and } \\
\text { Hyperferritinemia are } \\
\text { associated with Impaired } \\
\text { Survival in Patients } \\
\text { Diagnosed with } \\
\text { Myelodysplastic Syndromes: } \\
\text { Results from the First Polish } \\
\text { MDS-PALG Registry }\end{array}$ & $\begin{array}{l}\text { Elevated serum ferritin } \\
\text { level and decreased } \\
\text { overall survival }\end{array}$ & $\begin{array}{l}\text { Low risk; } \\
\text { Intermediate-1; } \\
\text { Intermediate-2; } \\
\text { high risk }\end{array}$ & No detailed usage \\
\hline $\begin{array}{l}\text { Remacha, } \\
\text { et al. } \\
\text { (2015) }\end{array}$ & $\begin{array}{l}\text { Evolution of iron overload in } \\
\text { patients with low-risk } \\
\text { myelodysplastic syndrome: } \\
\text { iron chelation therapy and } \\
\text { organ complications }\end{array}$ & $\begin{array}{c}\text { Elevated serum ferritin } \\
\text { level, Cardiac } \\
\text { complications }(20.2 \%), \\
\text { Hepatic }(11.4 \%), \\
\text { Endocrine }(9.9 \%), \\
\text { Arthropathies }(3.8 \%) \\
\end{array}$ & $\begin{array}{c}\text { Low } \\
\text { risk/Intermediate-1 }\end{array}$ & $\begin{array}{c}\text { Use of Deferasirox, } \\
\text { Deferoxamine and } \\
\text { Deferiprone. } \\
\text { Decreased serum } \\
\text { ferritin, increased } \\
\text { survival free from }\end{array}$ \\
\hline
\end{tabular}


Clinical Complications of Iron Overload in Patients with Myelodysplastic Syndrome

\begin{tabular}{|c|c|c|c|c|}
\hline & & & & $\begin{array}{l}\text { leukemia and } \\
\text { cardiac events }\end{array}$ \\
\hline $\begin{array}{c}\text { De Souza, } \\
\text { et al. } \\
\text { (2015) }\end{array}$ & $\begin{array}{c}\text { HFE gene mutation and } \\
\text { oxidative } \\
\text { damage biomarkers in } \\
\text { patients with } \\
\text { myelodysplastic syndromes } \\
\text { and its relation to } \\
\text { transfusional iron overload: } \\
\text { an observational cross- } \\
\text { sectional study }\end{array}$ & $\begin{array}{c}\text { High concentration of } \\
\text { malondialdehyde (MDA, } \\
\text { lipid peroxidation } \\
\text { indicator/oxidative stress). } \\
\text { Decreased overall } \\
\text { survival, cardiac, hepatic } \\
\text { and endocrine } \\
\text { dysfunction, leukemic } \\
\text { progression and infectious } \\
\text { complications }\end{array}$ & $\begin{array}{c}\text { Low risk; } \\
\text { Intermediate-1; } \\
\text { Intermediate-2; } \\
\text { high risk; unknown }\end{array}$ & Not used \\
\hline $\begin{array}{l}\text { Wong; } \\
\text { Wong; } \\
\text { Leitch, } \\
\text { (2018) }\end{array}$ & $\begin{array}{c}\text { Iron Overload in Lower } \\
\text { International Prognostic } \\
\text { Scoring System Risk Patients } \\
\text { with Myelodysplastic } \\
\text { Syndrome Receiving Red } \\
\text { Blood Cell Transfusions: } \\
\text { Relation to Infections and } \\
\text { Possible Benefit of Iron } \\
\text { Chelation Therapy }\end{array}$ & $\begin{array}{c}\text { Adverse effect on } \\
\text { neutrophils, increased } \\
\text { predisposition to } \\
\text { infections. }\end{array}$ & $\begin{array}{c}\text { Very low risk; low; } \\
\text { intermediary; high; } \\
\text { very high }\end{array}$ & $\begin{array}{c}\text { Use of Deferasirox, } \\
\text { Deferoxamine and } \\
\text { Deferiprone. } \\
\text { Chelation has } \\
\text { improved overall } \\
\text { survival and may } \\
\text { decrease the risk } \\
\text { of infection }\end{array}$ \\
\hline
\end{tabular}

The accumulation of iron in organs is a conditioning factor, mainly related to a decrease in overall survival. In our study, $43 \%$ of the reviewed studies had liver, cardiac, pancreatic or endocrine dysfunction, related to iron overload or the presence of deposits in these organs, and only one of them reported complications in joints.

Regarding cell viability, three studies (43\%) showed that iron overload can cause cell cycle arrest, compromising the functioning of the marrow, contributing to cell apoptosis, especially erythrocytes.

Levels of reactive oxygen species were assessed by two studies that noted the increase associated with overload, as well as in cell cultures from MDS patients with stimulated iron overload.

Infections, mainly bacterial, are strongly linked to iron overload in MDS. Only one study reported that iron causes adverse effects on neutrophils, making them ineffective, contributing to an increased predisposition to infections.

The use of iron chelators such as deferasirox, deferoxamine and deferiprone proved to be efficient when used $(71.4 \%)$. The treatment reduced serum ferritin, increased overall survival and survival without progression to leukemia, attenuated cardiac complications, decreased the risk of infection, improved cell viability and reduced ROS levels. Of the reviewed studies, $28.6 \%$ did not use chelators or did not detail how and which were used.

\section{Discussion and Conclusion}

Anemia is a predictive factor for iron overload in MDS, being the most common cytopenia in the disease, being 
associated with the need for transfusions in low-risk patients, corroborating with the accumulation of iron [6]. All studies reviewed included the follow-up of low-risk patients, reinforcing the relationship between anemia and transfusional iron overload in this group.

According to Gattermann [2], transfusion dependence is linked to decreased survival, being the most important cause of iron overload in MDS. However, overload begins before transfusion dependence, as ineffective erythropoiesis suppresses hepcidin production in the liver, leading to unrestricted intestinal iron uptake [8].

Iron overload associated with transfusion dependence on red blood cells is an accentuated factor for the risk of cardiac failure and death, as well as liver disease and a higher prevalence of diabetes mellitus, than patients not dependent on transfusion $[9,10]$.

The accumulation of iron in organs of patients with MDS is a finding present in the disease, with the liver, heart and pancreas being the most affected organs [7,11].

Increased cell death and apoptosis also occurred in the heart, liver and endocrine organs, due to the accumulation of these toxic iron species, causing damage not only to solid organs but also to the immune system and bone marrow, increasing the risk of progression to AML, as well as decreased survival $[9,10]$ Cell cycle blockage due to iron overload was pointed out in the work of Zheng [12] and Hua [13].

Hua et al. [13] described that in NK cells there is a decrease in the expression of p38, which increases apoptosis through the increased expression of JNK, an apoptosis regulatory protein. This compromises the innate immunity, as well as the overexpression of p38 in CD34+ cells in environments with iron overload, which decreases the apoptosis of these cells, leading to an increase in blast cells in the bone marrow and the progression of the disease to AML .

A systematic modeling study showed similar results, showing that both normal and MDS samples undergo apoptosis induced by TNF-a due to the activation of p38 and JNK. Activated p38 MAPK and JNK phosphorylate three types of proteins including BCL$\mathrm{XL}$, p53 and c-Jun, which lead to apoptosis of these cells [14].

Similarly, in CD34+ and CD38 immature hematopoietic progenitor cells, BCL-XL, an anti-apoptotic protein, was minimally expressed in MDS marrow due to p38 MAPK overactivation with increased apoptosis and ineffective hematopoiesis [14] .

The accumulation of free iron was responsible for the increase in ROS levels, causing an increase in erythroid apoptosis, through the low expression of HIF-1a, an important transcription factor in the regulation of the response to cellular hypoxia [12]. 
On the other hand, overexpression of HIF-1a reduced proapoptotic proteins and elevated antiapoptotic proteins in models of iron overload of SKM-1/K562 cells, demonstrating that overload can stimulate the mitochondrial apoptotic pathway, through the pathway of HIF1a/ROS signaling, triggering the mitochondrial dependent apoptotic pathway, in MDS patients, demonstrating that the HIF-1a/ROS signaling pathway is involved in damage-mediated iron overload [12]. In the study by Meng [15], carried out with mice exposed to benzene, it was possible to observe significantly increased ROS levels and decreased HIF-1a protein levels in the bone marrow.

The accumulation of iron generates high levels of ROS, resulting in damage to solid organs, immune system, bone marrow and decreased survival in individuals with MDS [10]. Shenoy et al. [6] reported that the oxidation of lipids, proteins and nucleic acids due to high levels of ROS associated with iron overload results in premature apoptosis, cell death, tissue and organ damage such as liver cirrhosis, diabetes and cardiomyopathy, these complications can lead to death if not treated.

De Souza et al. [16] evaluated ROS concentrations by measuring malondialdehyde (MDA), an indicator of lipid peroxidation and oxidative stress. Elevated ROS level was correlated with decreased survival and leukemic progression.

Among other complications, overload can make patients more susceptible to infections, especially bacterial, which according to Pagano [17] and Shammo; Komrokji [10] is due to the direct effect of iron on bacterial and fungal growth, functioning as a source of nutrients, associated with the neutropenia present in most MDS patients.

The infections present in patients with MDS are related not only to neutropenia, but also due to dysfunctions of these cells in relation to differentiation in the multipotent stem cell compartment. These dysfunctions can lead to several defects in adherence, migration and diapedesis, deficit in chemotaxis, reduced activity of granular neutrophil enzymes [17].

In addition, excess iron can damage the mucosa, compromising innate immunity, generating natural resistance to infection, inhibition of cytokines responsible for the immune response, formation of nitric oxide and impairment of macrophage, neutrophil and $T$ cell functions [10,17 ].

Diagnosis of iron overload in MDS is usually performed by measuring serum ferritin, as this is a widely available and inexpensive methodology. However, as it is an acute phase protein, other tests must be evaluated together, as it is high in infections, inflammatory processes and malignancies. Therefore, concomitant C- 
reactive protein dosage is recommended [2].

Other methods of assessment and diagnosis can be used in the determination of iron overload, such as serum hepcidin and $\mathrm{T}^{*}$ magnetic resonance, the latter being considered the gold standard for the assessment of iron in the myocardium and liver, being able to quickly assess the content of iron in these organs and their functional parameters [18].

Serum ferritin was the most used marker in the studies reviewed for monitoring iron overload and its relationship with the decrease in survival shown in our study.

Iron chelation therapy was used in most of the studies reviewed, which demonstrates its great efficacy in patients with low IPSS prognostic risk. The medications used (Table 1) had a positive effect on reducing serum ferritin, and consequently on the other problems caused by the accumulation of iron, reversing them in most cases.

Transfusion history is an important indicator of iron overload, as the number of transfusions a patient receives will help in decisions about starting chelation therapy [2].

Patients on chelation therapy using deferoxamine and/or deferasirox had superior survival with increasing duration of treatment as well as increased survival without leukemia [19].

Transfusion-dependent MDS patients showed reduced serum ferritin levels and laterally reduced ALT and AST levels using the iron chelator deferasirox, making $11 \%$ of patients transfusion-independent [20].

On the other hand, adverse effects from the use of chelators can be an inconvenience. Granulocytopenia was reported as the most serious, limiting the use of deferiprone in the treatment of iron overload in patients with MDS, and deferoxamine, given parenterally, becomes inconvenient, negatively impacting the benefit, causing injection site reactions, ocular toxicity that requires monitoring [6], being contraindicated in patients with severe kidney disease, as its main delivery route is through the kidneys [21].

With the use of deferasirox, rash and increased serum creatinine, gastrointestinal toxicities including flatulence, diarrhea, loss of appetite and aversion to food, frequent symptoms resulting in discontinuation of chelation therapy, have been reported [21].

However, despite the adverse effects, there is evidence that iron chelation therapies may confer clinical benefit on patients at lower IPSS risk with MDS [6,19].

Due to the number of studies included in this review, we highlight the difficulty in recovering studies that address the consequences of iron overload in MDS, as most of those in the literature focus on the effectiveness of iron chelators in the treatment, failing to 
evaluate problems secondary to overload.

Given the above, we conclude that the main cause of iron overload in MDS is multiple red cell transfusions and its complications mainly involve decreased survival, disease progression to leukemia, cell cycle arrest contributing to cytopenias and infections, elevation in the level of species reactive oxygen, as well as organ dysfunction and endocrine problems.

Chelating therapy is effective when used in low-risk patients, decreasing the consequences of overload, improving patient clinic, and increasing leukemia-free survival. There is a need for further work to assess the consequences of iron overload for a better management of patients with MDS.

\section{References}

[1] Oscier DG. ABC of clinical haematology: The myelodysplastic syndromes. BMJ. 1997;314(7084):883883. doi:10.1136/bmj.314.7084.883

[2] Gattermann N, Rachmilewitz EA. Iron overload in MDSpathophysiology, diagnosis, and complications. Ann Hematol. 2011;90(1):1-10. doi:10.1007/s00277-0101091-1

[3] Racanelli AP, Falconi MA, Alves SCR, Lorand-Metze I. Alterações morfológicas no hemograma nas síndromes mielodisplásicas: sua relação com os tipos OMS e as alterações encontradas na imunofenotipagem. Journal of the Health Sciences Institute, 2014; 32(1):12-7.

[4] Angelucci E, Cianciulli P, Finelli C, Mecucci C, Voso MT, Tura S. Unraveling the mechanisms behind iron overload and ineffective hematopoiesis in myelodysplastic syndromes. Leukemia Research. 2017;62:108-115. doi:10.1016/j.leukres.2017.10.001

[5] Greenberg PL, Tuechler H, Schanz J, Sanz G, Garcia-Manero G, Solé F, Bennett JM, Bowen D, Fenaux P, Dreyfus F, Kantarjian H, Kuendgen A, Levis A, Malcovati L, Cazzola M, Cermak J, Fonatsch C, Le Beau MM, Slovak ML, Krieger O, Luebbert M, Maciejewski J, Magalhaes SMM, Miyazaki Y, Pfeilstöcker M, Sekeres M, Sperr WR, Stauder R, Tauro S, Valent P, Vallespi $T$, van de Loosdrecht AA, Germing U, Haase D. Revised International Prognostic Scoring System for Myelodysplastic Syndromes. Blood. 2012;120(12):2454-2465.

doi:10.1182/blood-2012-03-420489

[6] Shenoy N, Vallumsetla N, Rachmilewitz E, Verma A, Ginzburg Y. Impact of iron overload and potential benefit from iron chelation in low-risk myelodysplastic syndrome. Blood. 2014;124(6):873-881. doi:10.1182/blood2014-03-563221

[7] On behalf of the IRON-2 Study Group, Remacha ÁF, Arrizabalaga B, Villegas A, Durán MS, Hermosín L, de 
Paz R, Garcia M, Campelo MD, Sanz G. Evolution of iron overload in patients with low-risk myelodysplastic syndrome: iron chelation therapy and organ complications. Ann Hematol. 2015;94(5):779-787. doi:10.1007/s00277014-2274-y

[8] Gattermann N. Iron overload in myelodysplastic syndromes (MDS). Int J Hematol. 2018;107(1):55-63. doi:10.1007/s12185-017-2367-1

[9] Ko B-S, Chang C-S, Chang M-C, Chen TY, Chiou T-J, Chiu C-F, Huang W-L, Kao W-Y, Lan Y-J, Lin S-F, Tan TD, Tang J-L, Tzeng C-H, Wang P-N, Yet S-P, Tien H-F. Guidelines for treating iron overload in myelodysplastic syndromes: a Taiwan consensus statement. Int J Hematol. 2014;100(1):715. doi:10.1007/s12185-014-1607-x

[10] Shammo JM, Komrokji RS. Clinical consequences of iron overload in patients with myelodysplastic syndromes: the case for iron chelation therapy. Expert Review of Hematology. 2018;11(7):577-586.

doi:10.1080/17474086.2018.1486188

[11] Du Y, Long Z, Chen M, Han B, Hou B, Feng F. Observational Monitoring of Patients with Aplastic Anemia and Low/Intermediate-1 Risk of Myelodysplastic Syndromes Complicated with Iron Overload. Acta Haematol. 2017;138(2):119-128. doi:10.1159/000479422
[12] Zheng Q, Zhao Y, Guo J, Zhao S, Song L, Fei C, Zhang Z, Li X, Chang C. Iron overload promotes erythroid apoptosis through regulating HIF1a/ROS signaling pathway in patients with myelodysplastic syndrome. Leukemia Research. 2017;58:55-62. doi:10.1016/j.leukres.2017.04.005

[13] Hua $\mathrm{Y}$, Wang C, Jiang $\mathrm{H}$, Wang Y, Liu C, Li L, Liu H, Shao Z, Fu R. Iron overload may promote alteration of NK cells and hematopoietic stem/progenitor cells by JNK and P38 pathway in myelodysplastic syndromes. Int J Hematol. 2017;106(2):248-257. doi:10.1007/s12185-017-2237-x

[14] Peng H, Wen J, Zhang L, Li H, Chang C-C, Zu Y, Zhou X. A systematic modeling study on the pathogenic role of p38 MAPK activation in myelodysplastic syndromes. Mol BioSyst. 2012;8(4):1366. doi:10.1039/c2mb05184b

[15] Meng X, Zhang J, Yin L, Pu Y. Involvement of hypoxia-inducible factor-1 $\alpha$ (HIF-1 $\alpha)$ in inhibition of benzene on mouse hematopoietic system. Journal of Toxicology and Environmental Health, Part A. 2016;79(9-10):402-406. doi:10.1080/15287394.2016.1176616

[16] De Souza GF, Ribeiro HL, De Sousa JC, Heredia FF, De Freitas RM, Martins MRA, Goncalves RP, Pinheiro RF, Magalhaes SMM. HFE gene mutation and oxidative damage biomarkers in patients with 
myelodysplastic syndromes and its relation to transfusional iron overload: an observational cross-sectional study. BMJ Open. 2015;5(4):e006048-e006048. doi:10.1136/bmjopen-2014-006048

[17] Pagano L, Caira M. Risks for infection in patients with myelodysplasia and acute leukemia. Current Opinion in Infectious Diseases. 2012;25(6):612-618.

doi:10.1097/QCO.0b013e328358b000

[18] Gu S, Song X, Zhao Y, Guo J, Fei C, Xu F, Wu L, Zhang X, Zhao J, Chang C, Li X. The Evaluation of iron overload through hepcidin level and its related factors in myelodysplastic syndromes. Hematology. 2013;18(5):286-294. doi:10.1179/1607845412Y.0000000064

[19] Leitch HA, Parmar A, Wells RA, Chodirker L, Zhu N, Nevill TJ, Yee KWL, Leber B, Keating M-M, Sabloff M, St. Hilaire E, Kumar R, Delage R, Geddes M, Storring JM, Kew A, Shamy A, Elemary M, Lenis M, Mamedov A, Ivo J, Francis J, Zhang L, Buckstein R. Overall survival in lower IPSS risk MDS by receipt of iron chelation therapy, adjusting for patient-related factors and measuring from time of first red blood cell transfusion dependence: an MDSCAN analysis. $\mathrm{Br} \mathrm{J}$ Haematol. 2017;179(1):83-97. doi:10.1111/bjh.14825

[20] Angelucci E, Santini V, Di Tucci AA, Quaresmini G, Finelli C, Volpe A, Quarta G, Rivellini F, Sanpaolo G, Cilloni D, Salvi F, Caocci G, Molteni A, Vallisa D, Voso MT, Fenu S, Borin L,
Latte G, Alimena G, Storti S, Piciocchi A, Fazi P, Vignetti M, Tura S. Deferasirox for transfusion-dependent patients with myelodysplastic syndromes: safety, efficacy, and beyond (GIMEMA MDS0306 Trial). Eur J Haematol. 2014;92(6):527-536. doi:10.1111/ejh.12300

[21] Zeidan AM, Griffiths EA. To chelate or not to chelate in MDS: That is the question! Blood Reviews. 2018;32(5):368-377.

doi:10.1016/j.blre.2018.03.002

Conflict of interest: The author declares no conflicts of interest.

Acknowledgements: To the professors and colleagues of the 2nd Class of the Postgraduate Course in Clinical Hematology and Blood Bank at Unichristus.

Funding: None.

How to cite this article: Carvalho LGA, Batista AHM, Sousa IC. Clinical Complications of Iron Overload in Patients with Myelodysplastic Syndromes: a literature review. Brazilian Journal of Case Reports. 2021 Abr-Jun;01(2):83-92. 